\title{
Decreased androstenedione production with increased follicular maturation in theca cells from the domestic hen (Gallus domesticus)
}

\author{
B. L. Marrone and F. Hertelendy \\ St Louis University School of Medicine, Departments of Obstetrics \& Gynecology and Physiology, \\ St Louis, Missouri 63104, U.S.A.
}

\begin{abstract}
Summary. Collagenase-dispersed theca cells from the 3rd and 4th largest ovarian follicles $\left(\mathrm{T}_{3}\right)$ were responsive to $\mathrm{LH}$ stimulation of both oestrogen and androstenedione production, whereas theca cells from the largest follicle $\left(T_{1}\right)$ failed to respond to the gonadotrophin stimulation. Similarly, 8-bromo cAMP and forskolin were more effective in stimulating oestrogen and androstenedione production in $T_{3}$ than in $T_{1}$ cells, indicating that post-receptor events were involved in the decreased $\mathrm{LH}$ responsiveness of $T_{1}$ cells. The C17-20-lyase activity, as measured by conversion of $\left[{ }^{3} \mathrm{H}\right] 1$ 7-hydroxyprogesterone to androstenedione, was greatly reduced in $\mathrm{T}_{1}$ cells as compared to $\mathrm{T}_{3}$ cells. The results demonstrate that a decrease in C17-20-lyase activity, in addition to a decrease in aromatase activity, contributes to the loss of LH-stimulated steroidogenesis in mature theca cells.
\end{abstract}

\section{Introduction}

The domestic hen has only one functional ovary and ovulates daily for several consecutive days. As the follicles mature, they become filled with yolk. The yolk-filled follicles are arranged in a size hierarchy, whereby the largest follicle ovulates first, followed by the next largest follicle $24 \mathrm{~h}$ later, and so on. The precise hierarchical arrangement of the follicles in a single ovary makes the hen attractive for investigation of the influence of follicular maturation on steroidogenesis by theca and granulosa cells.

The granulosa layer of the hen ovarian follicle is the primary source of progesterone and has virtually no aromatase activity, whereas the theca layer is the source of oestrogen (Huang, Kao \& Nalbandov, 1979; Wells, Dick \& Gilbert, 1981; Marrone \& Hertelendy, 1983b; Armstrong, 1984). The production of steroids during follicular maturation is regulated by $\mathbf{L H}$. As the follicle matures, from the 3 rd or 4th largest in the hierarchy to the largest, the $\mathrm{LH}$-stimulated progesterone release from the granulosa cells increases (Hammond, Burke \& Hertelendy, 1981 ; Asem, Lintner, Biellier, Burke \& Hertelendy, 1983). In contrast, theca cells from the 3rd largest follicle are more responsive to LH stimulation of oestrogen production than are theca cells from the follicle destined to ovulate next (Huang et al., 1979; Marrone \& Hertelendy, 1983b). Corresponding differences in the aromatase activity (Huang et al., 1979; Marrone \& Hertelendy, 1983b; Armstrong, 1984) have been interpreted to account for the diminished oestrogen response to LH stimulation in cells of the follicle nearest to ovulation.

Because androstenedione represents a major metabolite of progesterone in theca cells (Llewelyn, 1981a; Marrone \& Hertelendy, 1983a) its production was used as the end-point in the present study to determine whether impaired steroidogenic capacity observed during theca cell maturation was due solely to the well-documented decrease in aromatase activity or to other biosynthetic events before the conversion of androgen to oestrogen. 


\section{Materials and Methods}

Experimental animals. White Leghorn hens (1-2 years old) were obtained from the University of Missouri-Columbia or from Ralston Purina Farms, Gray Summit, MO. All birds used had regular clutches of at least 5 consecutive days, and the time of oviposition was recorded by an automatic device. The next ovulation in a clutch occurs 5-60 min after oviposition (Bahr \& Nalbandov, 1977). The birds were caged individually in a windowless room and kept under a lighting schedule of $14 \mathrm{~h}$ light/24 h. Purina Layena ration and water were provided ad libitum.

Hormones and chemicals. Ovine LH (NIAMDD-LH-22; $2 \cdot 3$ NIH-LH-S1/mg) was a gift from the National Pituitary Agency of the National Institutes of Health and was reported to contain $<0.5 \%$ FSH. The steroids, collagenase Type 1, 8-bromo cyclic AMP, and 3-isobutyl-1-methylxanthine (IBMX) were obtained from Sigma Chemical Co., St Louis, MO. Worthington (Freehold, $\mathrm{NJ})$ supplied the lima bean trypsin inhibitor. Forskolin was obtained from Calbiochem-Behring (San Diego, CA), and Medium 199 with Hank's salts was purchased from Grand Island Biological

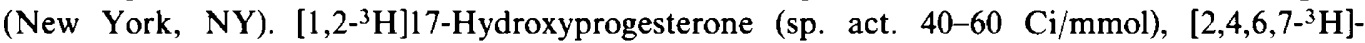
oestradiol-17ß (sp. act. $90-115 \mathrm{Ci} / \mathrm{mmol}$ ), and $\left[1,2,6,7-{ }^{3} \mathrm{H}\right]$ androstenedione (sp. act. $80-115$ $\mathrm{Ci} / \mathrm{mmol}$ ) were purchased from New England Nuclear Corp. (Boston, MA). Solvents for the highperformance liquid chromatography (HPLC) analysis were purchased from Fisher Scientific (Pittsburgh, PA) and Baker Chemical Co. (Phillipsburg, NJ).

Tissue collection and cell preparation. Birds were killed by cervical dislocation $1-4 \mathrm{~h}$ before expected ovulation. The yolk-filled follicles were removed and the theca layer was separated completely from the granulosa layer of the 3rd and 4th largest follicles (combined) and the largest follicle using the procedure described by Gilbert, Evans, Perry \& Davidson (1977). The follicle was held in $0.9 \%(\mathrm{w} / \mathrm{v}) \mathrm{NaCl}$ whilst a long incision was made in it with a pair of scissors. The yolk, with the adhering granulosa layer, fell away from the theca layer. The theca layer was cleaned of connective tissue, minced, and incubated for $1-2 \mathrm{~h}$ in a solution of $1250 \mathrm{U}$ collagenase and $0.3 \mathrm{mg}$ trypsin inhibitor in $3 \mathrm{ml}$ Medium 199 containing $10 \mathrm{~mm}$-Hepes and $0.1 \%$ bovine serum albumin. Enzymic digestion of the theca tissue was carried out at $37^{\circ} \mathrm{C}$ in a shaking water bath, open to the air. At 15-min intervals the cells were aspirated several times in a siliconized Pasteur pipette. When the preparation became homogeneous the cells were centrifuged at $4^{\circ} \mathrm{C}$ for $10 \mathrm{~min}$ at $800 \mathrm{~g}$. The cells were then washed twice with calcium- and magnesium-free phosphate-buffered $0.9 \%(\mathrm{w} / \mathrm{v})$ $\mathrm{NaCl}$ that contained $0.2 \%$ glucose. The cells were resuspended in Medium 199 and an aliquant was taken for cell count and viability estimation using a haemocytometer. Viability, as determined by exclusion of $0.01 \%$ trypan blue, was always greater than $90 \%$. Each cell preparation was diluted to a final concentration of $1 \times 10^{6}$ viable cells/ml Medium 199.

Incubations. Cells $\left(2 \times 10^{5}\right)$ were pipetted into $12 \times 75 \mathrm{~mm}$ polystyrene culture tubes containing $0 \cdot 1 \mathrm{mM}$-IBMX and the treatment substance in Medium 199. The final volume of the tubes was $1 \mathrm{ml}$. Cells were incubated for $3 \mathrm{~h}$ (or $5 \mathrm{~h}$ in the HPLC study) at $37^{\circ} \mathrm{C}$ open to the air, in a shaking water bath. The incubations were terminated by immersing the tubes in an ice-water bath. The samples were frozen at $-10^{\circ} \mathrm{C}$ until extraction for radioimmunoassay or HPLC analysis.

Theca layers from 1-2 birds were used for each experiment. There were 5 replicate tubes per treatment group. Each experiment was repeated 1-3 times with similar results and the results of typical experiments are shown.

Radioimmunoassays. The incubation media and cells were extracted twice with 2 volumes of diethyl ether. The extraction efficiencies for both oestrogen and androstenedione were $>95 \%$. The extract was evaporated to dryness and redissolved in ethyl alcohol; $75 \%$ of the sample was taken for oestrogen radioimmunoassay and $5-20 \%$ was taken for androstenedione radioimmunoassay.

The radioimmunoassay for oestradiol and oestrone has been described previously (Hammond, Olson, Frenkel, Biellier \& Hertelendy, 1980; Marrone \& Hertelendy, 1983b). The oestrogen 
antiserum (provided by Dr B. V. Caldwell, Yale University) reacts equally well with oestradiol-17 $\beta$ and oestrone and has a $10 \%$ cross-reactivity with oestriol and $<0.1 \%$ cross-reactivity with other steroids. Parallelism was determined by measuring the oestrogen concentration in different volumes of the extracted sample. In $10 \%, 25 \%, 50 \%, 75 \%$ and $100 \%$ of the extracted sample the concentrations of oestrogen were $3.73 \pm 0 \cdot 11,3.56 \pm 0 \cdot 13,3.22 \pm 0 \cdot 11,3.26 \pm 0.09$, and 3.09 \pm $0.15 \mathrm{pg} / \mu \mathrm{l}$, respectively. The inter- and intra-assay coefficients of variation were $11 \%$ and $5 \%$, respectively, and the sensitivity was $10 \mathrm{pg}$. The sample aliquant was added to a $10 \times 75 \mathrm{~mm}$ borosilicate tube and evaporated to dryness. The antiserum (final dilution $1: 40000)$, label (10 000

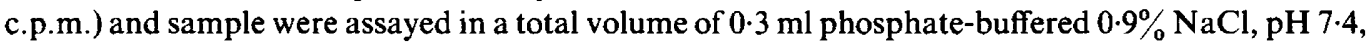
containing $0.1 \%$ gelatin (PBS-G). After an overnight incubation at $4{ }^{\circ} \mathrm{C}, 0.6 \mathrm{ml}$ of a $0.25 \%$ charcoal $/ 0.25 \%$ dextran suspension in PBS-G were added to each tube and the tubes were centrifuged at $800 \mathrm{~g}$ and $4^{\circ} \mathrm{C}$. The supernatant was decanted into polypropylene mini-vials containing $5.8 \mathrm{ml}$ of a toluene-based scintillation cocktail with Triton X-100 added. They were counted in a Beckman LS-7000 scintillation counter with a setting of $2 \%$ error.

The androstenedione antiserum (ANS-22 from Endocrine Sciences, Tarzana, CA) cross-reacts with 1,4-androstadiene-3,17-dione $(40 \%), 5 \alpha$ - and $5 \beta$-androstan-3,17-dione $(35 \%)$, androsterone and epiandrosterone $(4 \%)$, androstane $(3.5 \%), 5 \alpha$-androstan-3,11,17-trione $(2 \cdot 5 \%)$, and testosterone $(2 \%)$. Parallelism was determined by measuring the androstenedione concentration in different volumes of the extracted sample. In $10 \%, 5 \%, 2 \%$ and $1 \%$ of the extracted sample, the concentrations of androstenedione were $3.52 \pm 0.17,4.05 \pm 0.18,3.33 \pm 0.71$ and $3.55 \pm 0.06$ $\mathrm{pg} / \mu \mathrm{l}$, respectively. Cross-reactivity with other androgens and pregnane compounds was $<1 \%$. The coefficients for inter- and intra-assay variation were both $10-11 \%$. The sensitivity of the assay was 5 pg. An aliquant of the sample was evaporated to dryness in the radioimmunoassay tube and the antiserum (at a final dilution of $1: 2000)$ and label $(10000$ c.p.m.) were incubated with the sample in a final volume of $0.2 \mathrm{ml}$ PBS-G overnight at $4^{\circ} \mathrm{C}$. The remainder of the procedure was the same as for the oestrogen radioimmunoassay.

Samples from each experiment were analysed in the same radioimmunoassay.

HPLC. Details of the HPLC analysis have been reported previously (Marrone \& Hertelendy, 1983a). After incubation of cells with $8 \times 10^{-7} \mathrm{M}-\left[{ }^{3} \mathrm{H}\right] 17$-hydroxyprogesterone for $5 \mathrm{~h}$, the cells and media were extracted twice with 2 volumes of diethyl ether and the extracts were evaporated to dryness in a $45^{\circ} \mathrm{C}$ water bath under a stream of nitrogen. The residue was dissolved in $25 \mu \mathrm{l} \mathrm{HPLC}$ grade methanol and $20 \mu \mathrm{l}$ of the sample were injected through an Altex fixed-volume injector onto a reversed-phase $\mathrm{C} 18$ column (Altex Ultrasphere, $5 \mu \mathrm{m}$; column dimensions: $15 \mathrm{~cm} \times 4.6 \mathrm{~mm}$ ). The mobile phase was tetrahydrofuran : methanol : water $(16: 28: 56$, by vol.) at a flow rate of $1 \mathrm{ml} / \mathrm{min}$ (Darney, Wing \& Ewing, 1983). Fractions were collected at $0 \cdot 5-\mathrm{min}$ intervals for scintillation counting and the profile was visualized by u.v. spectroscopy at $240 \mathrm{~nm}$. The apparatus was equipped with a Beckman pump (Model 110A) and microprocessor (Model 420), and a Hitachi spectrometer (Model 110-10). A Shimadzu C-RIA integrator/recorder recorded the spectrometry data.

Fractions were collected for $30 \mathrm{~min}$ and the total radioactivity in 60 fractions was calculated. The production of each steroid metabolite was based on coelution of radioactivity with a known steroid standard. The radioactivity in each peak was expressed as a percentage of the total radioactivity. Only fractions with radioactivity twice that of background were used in the calculations.

Data analysis. The means and standard errors were derived from 5 replicate samples in each treatment group. Comparisons between 2 groups were analysed by Student's $t$ test. When results were compared amongst more than 2 groups they were analysed by one-way analysis of variance followed by Neuman-Keuls test. Probability values of $<0.05$ were considered to be statistically significant. 


\section{Results}

LH treatment significantly increased oestrogen and androstenedione production by theca cells of the 3rd largest follicle (Text-fig. 1). In contrast, oestrogen production in theca cells of the largest follicle was not influenced by even the highest dose of LH. The maximal response of androstenedione to $\mathrm{LH}$ was over 10 -fold in $T_{3}$ cells, whereas only a 2 -fold increase in $T_{1}$ cells was seen. The decreased production of androstenedione and oestrogen in response to $L H$ in $T_{1}$ cells indicates that the aromatase deficiency in $T_{1}$ cells cannot alone account for their decreased steroidogenesis.

To detect whether the decreased LH-responsiveness of $T_{1}$ cells occurred at the LH-receptor level or beyond, $T_{1}$ and $T_{3}$ cells were treated with 8-bromo cAMP. In $T_{3}$ cells, 8-bromo cAMP significantly increased oestrogen and androstenedione production (Text-fig. 2), whereas $T_{1}$ cells failed to respond to the doses of 8-bromo cAMP used in this study.

We also compared androstenedione and oestrogen production in $T_{1}$ and $T_{3}$ cells in response to forskolin, an intracellular activator of adenylate cyclase. Forskolin significantly increased oestrogen production in $T_{3}$ cells, but not in $T_{1}$ cells (Text-fig. 3). Maximal forskolin-stimulated production of androstenedione in $T_{1}$ cells, although significant, was 4-5-fold, whereas in $T_{3}$ cells forskolin induced a 9-fold increase. The results presented in Text-figs 2 and 3 indicate that the reduction in steroidogenesis exhibited by $T_{1}$ cells is due to a step(s) beyond activation of the adenylate cyclase.

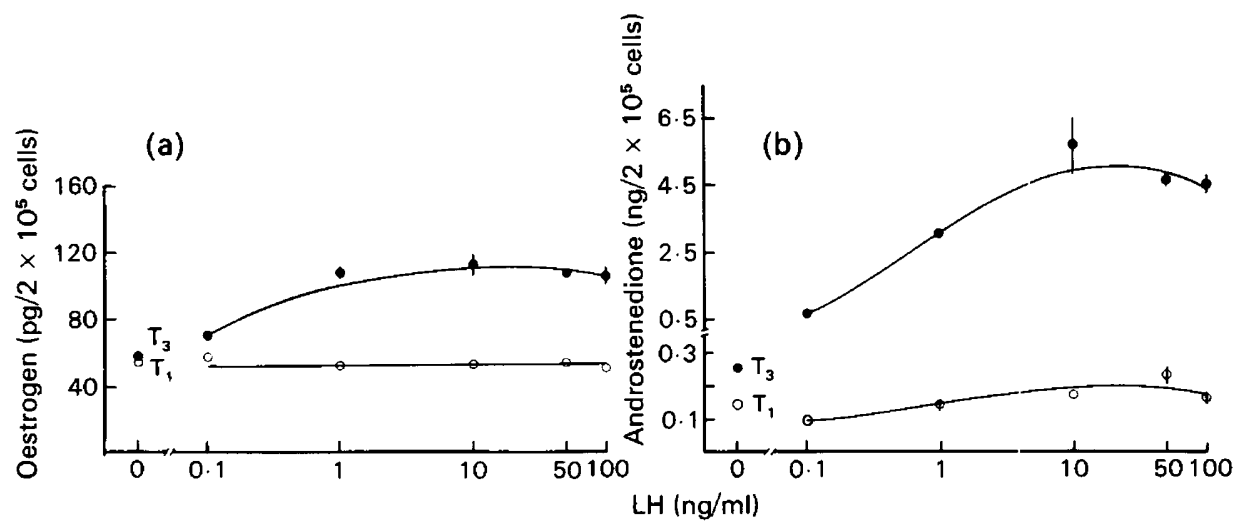

Text-fig. 1. Effect of LH on production of (a) oestrogen and (b) androstenedione by theca cells from the largest $\left(T_{1}\right)$ and 3 rd and 4th largest $\left(T_{3}\right)$ follicles collected $2 \mathrm{~h}$ before expected ovulation. Cells $\left(2 \times 10^{5} / \mathrm{ml}\right)$ were incubated for $3 \mathrm{~h}$ at $37^{\circ} \mathrm{C}$. Each point represents the mean \pm s.e.m. of 5 replicate samples from 1 out of 4 separate experiments.

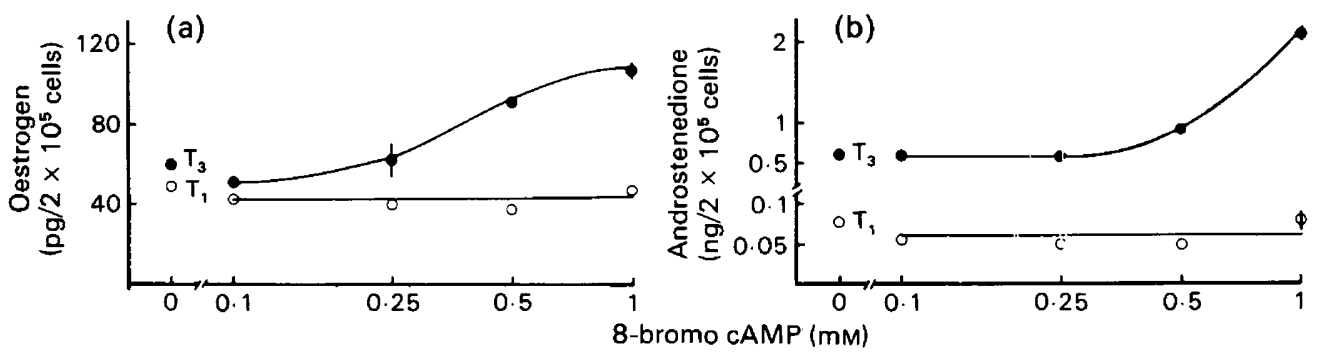

Text-fig. 2. Effect of 8-bromo cAMP on production of (a) oestrogen and (b) androstenedione by theca cells from the largest $\left(T_{1}\right)$ and 3 rd and 4th largest $\left(T_{3}\right)$ follicles collected $2 \mathrm{~h}$ before expected ovulation. Cells $\left(2 \times 10^{5} / \mathrm{ml}\right)$ were incubated for $3 \mathrm{~h}$ at $37^{\circ} \mathrm{C}$. Each point represents the mean \pm s.e.m. of 5 replicate samples from 1 experiment out of 2 separate experiments. 

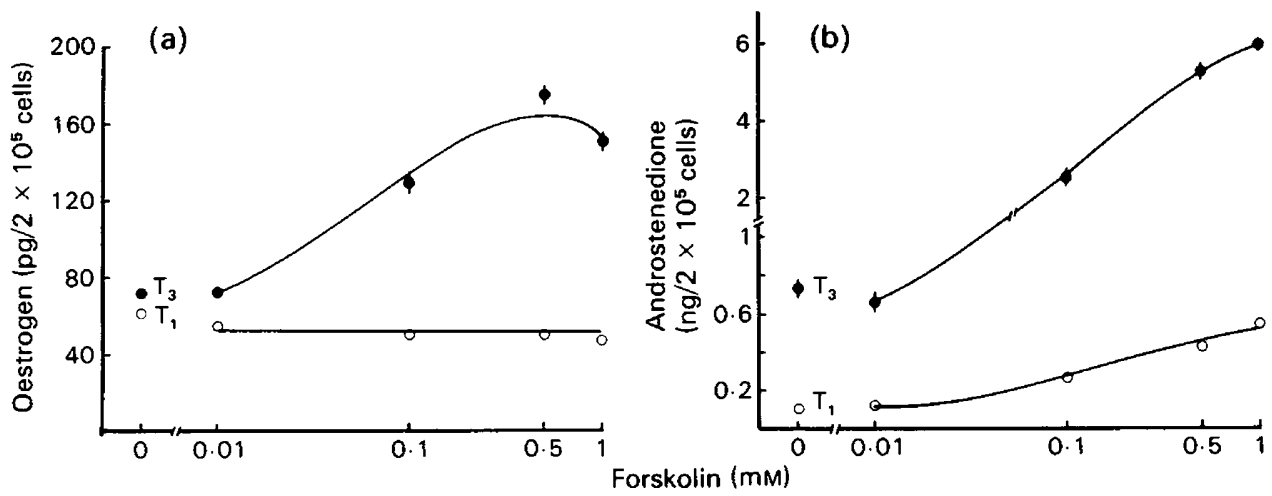

Text-fig. 3. Effect of forskolin on production of (a) oestrogen and (b) androstenedione by theca cells from the largest $\left(T_{1}\right)$ and 3 rd and 4 th largest $\left(T_{3}\right)$ follicles collected $2 \mathrm{~h}$ before expected ovulation. Cells $\left(2 \times 10^{5} / \mathrm{ml}\right)$ were incubated for $3 \mathrm{~h}$ at $37^{\circ} \mathrm{C}$. Each point represents the mean \pm s.e.m. of 5 replicate samples from 1 experiment out of 3 separate experiments.

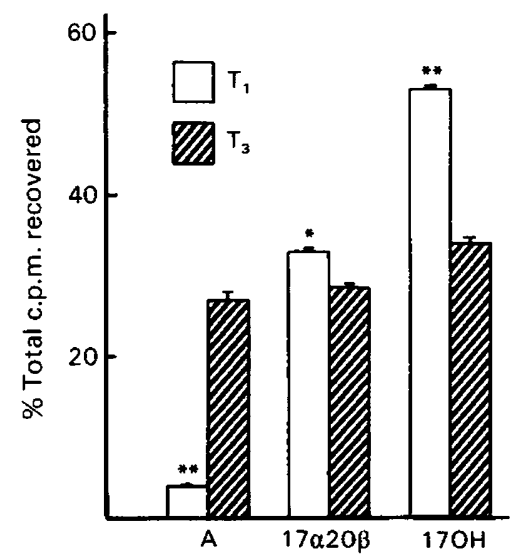

Text-fig. 4. $\left[{ }^{3} \mathrm{H}\right] 1$-Hydroxyprogesterone metabolism by theca cells from the largest $\left(\mathrm{T}_{1}\right)$ and 3 rd and 4 th largest $\left(T_{3}\right)$ follicles collected $2 \mathrm{~h}$ before expected ovulation. Cells $\left(2 \times 10^{5} / \mathrm{ml}\right)$ were incubated for $5 \mathrm{~h}$ with $8 \times 10^{-7} \mathrm{M}-\left[{ }^{3} \mathrm{H}\right] 17$-hydroxyprogesterone and labelled metabolites were separated by HPLC. The percentage of the total radioactivity recovered as androstenedione (A), 17 $\alpha, 20 \beta$-dihydro-4-pregnen-3-one (17 $\alpha 20 \beta)$, and substrate $(17 \mathrm{OH})$ is expressed as the mean \pm s.e.m. of 5 replicate samples from 1 experiment out of 3 separate experiments. Compared with corresponding value for $\mathrm{T}_{3},{ }^{*} P<0.05,{ }^{* *} P<0.001$.

Androstenedione is the product of the C17-20-lyase activity. The production of androstenedione directly from 17-hydroxyprogesterone in $T_{1}$ and $T_{3}$ cells was compared by HPLC analysis and the results presented in Text-fig. 4 . Incubation of $\mathrm{T}_{3}$ cells with [ $\left.{ }^{3} \mathrm{H}\right] 17$-hydroxyprogesterone yielded 2 major metabolites: androstenedione and 17 $\alpha, 20 \beta$-dihydroxy-4-pregnen-3-one. The retention times of the substrate peak, 17 $\alpha, 20 \beta$-dihydroxy-4-pregnen-3-one, and androstenedione were 20,17 and $10 \mathrm{~min}$, respectively. The retention times of the major peaks are well separated from testosterone, the $20 \alpha$-reduced metabolite of 17-hydroxyprogesterone and oestrogens, although the amounts of these steroids detected in this system account for $<1 \%$ of the total radioactivity. By comparison to $T_{3}$, significantly less $(\sim 19 \%)$ of the substrate was utilized by $T_{1}$ cells. This decreased substrate utilization by $T_{1}$ cells was reflected in significantly less $(\sim 23 \%)$ androstenedione production. In addition, the percentage of $17 \alpha, 20 \beta$-dihydroxy-4-pregnen-3-one in $T_{1}$ cells was slightly, but significantly, higher than in $T_{3}$ cells. 


\section{Discussion}

Androstenedione production was stimulated greatly by $\mathrm{LH}$ in theca cells from the $3 \mathrm{rd}$ and 4th largest follicles, but not in theca cells from the largest, most mature, preovulatory follicle. These results are in agreement with previous findings that oestrogen production is stimulated by $\mathrm{LH}$ in $\mathrm{T}_{3}$ but not in $T_{1}$ cells (Huang et al., 1979; Marrone \& Hertelendy, 1983b). The reason for the lack of oestrogen production in $\mathrm{T}_{1}$ cells in response to $\mathrm{LH}$ has been inferred, previously, to be due to a marked decrease in aromatase activity in $T_{1}$ cells. The decreased androstenedione production by $\mathrm{T}_{1}$ cells in response to $\mathrm{LH}$ in the present study indicates that decreased aromatase activity in mature theca cells cannot alone account for their decreased LH responsiveness. By using androstenedione production in response to $\mathrm{LH}$ stimulation as an end-point we have demonstrated that a change before the aromatase step contributed to the decreased steroidogenesis in $\mathrm{T}_{1}$ cells. That the decreased androstenedione production was due to post-receptor events was documented by the relative lack of responsiveness of $T_{1}$ cells, as compared to $T_{3}$ cells, to 8-bromo cAMP and forskolin, both of which act distally to the hormone receptor level. These results pointed to an impaired biosynthesis of androstenedione in theca cells during maturation.

By the use of HPLC analysis of $\left[{ }^{3} \mathrm{H}\right] 17$-hydroxyprogesterone metabolism in the present study we were able to determine that the $\mathrm{C} 17-20$-lyase activity was decreased significantly as theca cells matured from $T_{3}$ to $T_{1}$. This decreased conversion of 17-hydroxyprogesterone to androstenedione was accompanied by a significant decrease in the utilization of $\left[{ }^{3} \mathrm{H}\right] 17$-hydroxyprogesterone substrate. Therefore, in addition to the decrease in aromatase activity found previously in $T_{1}$ cells, these cells appear to be deficient in C17-20-lyase activity.

The activities of other steroid biosynthetic enzymes may also be decreased in theca cells during the last few days of follicular maturation. In a previous study of $\left[{ }^{3} \mathrm{H}\right]$ progesterone metabolism by theca cells we noticed that more substrate was utilized by $T_{3}$ cells than by $T_{1}$ cells. The reduced substrate utilization by $T_{1}$ cells appeared to be reflected partly by reduced accumulation of 17hydroxyprogesterone and androstenedione (Marrone \& Hertelendy, 1983a). The activity of $17 \alpha-$ hydroxylase may also be reduced in $T_{1}$ cells. Other studies have suggested that the activities of the ovarian C17-20-lyase and 17 $\alpha$-hydroxylase enzymes are closely related (Bogovich \& Richards, 1982; Chasalow, Marr \& Taylor, 1982; Johnson, Martin \& Tsai-Morris, 1984). In addition, Armstrong (1982) has shown that thecal $3 \beta$-hydroxy- $\Lambda^{5}$-steroid dehydrogenase activity reaches a maximum in the 3 rd and 4 th largest preovulatory follicles of the hen and its activity declines therafter as the follicle approaches ovulation. Therefore, the composite picture of thecal steroidogenesis during maturation from the 3rd and 4th largest follicles to the largest follicle in the hierarchy shows parallel decreases in the activities of multiple steroidogenic enzymes. A possible exception to this pattern is the 20ß-hydroxysteroid dehydrogenase activity, which appeared to be slightly greater in the $T_{1}$ cells than in the $T_{3}$ cells in the present study. Similarly, the production of $20 \beta$-hydroxy-4-pregnen-3-one from $\left[{ }^{3} \mathrm{H}\right]$ progesterone was greater in theca cells from the largest follicle than from the 2 nd or 3 rd largest follicle (Llewelyn, 1981b). Therefore, unlike the aromatase and C17-20-lyase activities, the 20ß-hydroxysteroid dehydrogenase activity of theca cells is not decreased and may, in fact, be increased in follicles at about the time of ovulation.

Since FSH has been shown to bind to the theca layer of the hen ovarian follicle one may consider the possibility that FSH is the active gonadotrophin in the more mature theca cells that become refractory to LH stimulation. However, binding of FSH to theca homogenates is greater in the 3rd and 4th largest follicles than in the largest follicle (Etches \& Cheng, 1981). Assuming that FSH acts through a cAMP-mediated mechanism in ovarian cells (Hsueh, Adashi, Jones \& Welsh, 1984), the findings of the present study, that both 8-bromo cAMP and forskolin were less effective in $T_{1}$ cells than in $T_{3}$ cells, argues against the possibility that FSH is the active gonadotrophin in $T_{1}$ cells.

Juxtaposed with decreasing activities of steroidogenic enzymes in theca cells, the granulosa cells acquire increased sensitivity to LH stimulation of progesterone production during the last 3-4 
days of follicular maturation (Huang et al., 1979; Hammond et al., 1981; Asem et al., 1983; Marrone \& Hertelendy, 1983b). These events suggest that an interaction between theca and granulosa cells may be responsible for the divergent steroidogenic abilities of these cells as they mature. Perhaps a product of the theca cells enhances granulosa cell steroidogenesis. A synergistic effect of oestrogen and FSH on $\mathrm{LH}$ receptor induction has been well-established in mammalian ovarian cells (Richards \& Midgley, 1976). Oestrogen production by the less mature theca cells may participate in the induction of $\mathrm{LH}$ receptors on the granulosa cells of the same follicle. Conversely, the increased progesterone production by maturing granulosa cells may influence subsequent theca cell steroidogenesis, perhaps by inhibiting the aromatase or C17-20-lyase activities. Alternatively, $\mathrm{LH}$ receptors on theca cells may undergo down-regulation as the follicle matures and this downregulation may be accompanied by steroidogenic lesions. In Leydig cells, down-regulation of LH receptors occurs after exposure to high levels of $\mathrm{LH}$ and the receptor down-regulation is accompanied by losses in steroid enzyme activities (Dufau et al., 1984).

The results of the present study have characterized further the changes in steroidogenesis by theca cells that occur during the late stages of follicular maturation in the hen ovary. The goals of future studies will be to determine the factors that induce these changes in steroid enzyme activities and to understand the interaction of the theca and granulosa cells in this process.

Supported by NIH grant HD16623 and a Basic Research Support Grant (to BLM) and NIH grant HD09763 (to FH). Mr Duane Stebler of Ralston Purina Research Farms, Gray Summit, MO and $\mathrm{Dr}$ Harold Biellier, University of Missouri-Columbia, MO, generously supplied the experimental animals. We thank Ms Wafaa Eleissawy for technical assistance and Ms Charlene Sandler for secretarial assistance.

\section{References}

Armstrong, D.G. (1982) 3ß-Hydroxy- $\Delta^{5}$-steroid dehydrogenase activity in the rapidly growing ovarian follicles of the domestic fowl (Gallus domesticus). $J$. Endocr. 93, 415-421.

Armstrong, D.G. (1984) Ovarian aromatase activity in the domestic fowl (Gallus domesticus). J. Endocr. 100, 81-86.

Asem, E.K., Lintner, F., Biellier, H.V., Burke, W.H. \& Hertelendy, F. (1983) Comparison of turkey luteinizing hormone (LH)- and ovine $\mathrm{LH}$-induced progesterone production in granulosa cells of the turkey (Meleagris gallopavo) and of the domestic fowl (Gallus domesticus). Gen. comp. Endocr. 52, 445-451.

Bahr, J.M. \& Nalbandov, A.V. (1977) Reproduction in poultry. In Reproduction in Domestic Animals, 3rd edn, pp. 529-552. Eds H. H. Cole \& P. T. Cupps. Academic Press, New York.

Bogovich, K. \& Richards, J.S. (1982) Androgen biosynthesis in developing ovarian follicles: Evidence that luteinizing hormone regulates thecal $17 \alpha$-hydroxylase and C17,20-lyase activities. Endocrinology 111, 12011208.

Chasalow, F.I., Marr, H. \& Taylor, G. (1982) A new assay and solubilization procedure for steroid 17,20-lyase from rat testes. Steroids 39, 617-630.

Darney, K.J., Wing, T.Y. \& Ewing, L.L. (1983) Simultaneous measurement of four testicular $\Delta^{4}-3$ ketosteroids by isocratic high-performance liquid chromatography with on-line ultraviolet absorbance detection. J. Chromatog. 257, 81-90.
Dufau, M.L., Winters, C.A., Hattori, M., Aquilano, D., Baranao, J.L.S., Nozu, K. Baukal, A. \& Catt, K.J. (1984) Hormonal regulation of androgen production by the Leydig cell. J. Steroid Biochem. 20, 161-173.

Etches, R.J. \& Cheng, K.W. (1981) Changes in the plasma concentrations of luteinizing hormone, progesterone, oestradiol and testosterone and in the binding of follicle-stimulating hormone to the theca of follicles during the ovulation cycle of the hen (Gallus domesticus). J.Endocr. 91, 11-22.

Gilbert, A.B., Evans, A.J., Perry, M.M. \& Davidson, M.H. (1977) A method for separating the granulosa cells, the basal lamina and the theca of the preovulatory ovarian follicle of the domestic fowl (Gallus domesticus). J. Reprod. Fert. 50, 179-181.

Hammond, R.W., Burke, W.H. \& Hertelendy, F. (1981) Influence of follicular maturation on progesterone release in chicken granulosa cells in response to turkey and ovine gonadotropins. Biol. Reprod. 24, 1048-1055.

Hammond, R.W., Olson, D.M., Frenkel, R.B., Biellier, H.V. \& Hertelendy, F. (1980) Prostaglandins and steroid hormones in plasma and ovarian follicles during the ovulation cycle of the domestic hen (Gallus domesticus). Gen. comp. Endocr. 42, 195-202.

Hsueh, A.J.W., Adashi, E.Y., Jones, P.B.C. \& Welsh, T.H. (1984) Hormonal regulation of the differentiation of cultured ovarian granulosa cells. Endocrine Rev. 5, 76-127.

Huang, E.S., Kao, K.J. \& Nalbandov, A.V. (1979) 
Synthesis of sex steroids by cellular components of chicken follicles. Biol. Reprod. 20, 454-461.

Johnson, D.C., Martin, H. \& Tsai-Morris, C.H. (1984) The in vitro and in vivo effect of estradiol upon the $17 \alpha$-hydroxylase and $C 17,20$-lyase activity in the ovaries of immature hypophysectomized rats. Molec. cell. Endocr. 35, 199-204.

Llewelyn, C.A. (1981a) Conversion of $\left[4^{-14}\right.$ C]progesterone to androstenedione in vitro by thecal tissue from the ovary of the domestic fowl (Gallus domesticus). $J$. Endocr. 89, 283-288.

Llewelyn, C.A. (1981b) Conversion of progesterone to $20 \beta$-hydroxy-4-pregnene-3-one by the preovulatory follicle in the hen (Gallus domesticus). IRCS Med. Sci. 9, 859 .
Marrone, B.L. \& Hertelendy, F. (1983a) Steroid metabolism by avian ovarian cells during follicular maturation. Biol. Reprod. 29, 953-962.

Marrone, B.L. \& Hertelendy, F. (1983b) Steroidogenesis by avian ovarian cells : effects of luteinizing hormone and substrate availability. Am. J. Physiol. 244, E487E493.

Richards, J.S. \& Midgley, A.R. (1976) Protein hormone action: a key to understanding ovarian follicular and luteal cell development. Biol. Reprod. 14, 82-94.

Wells, J.W., Dick, H.R. \& Gilbert, A.B. (1981) The biosynthesis of protesterone by fowl granulosa cells in vitro from ${ }^{14} \mathrm{C}$-labelled substrates. J. Steroid Biochem. 14, 651-656.

Received 2 October 1984 